Comparative Fruit Anatomy and Morphology of Four Species Known as Cumin (Kimyon) in Turkey

\author{
Hüseyin Onur TUNCAY1 ${ }^{\mathscr{Q}}$, Yeter YEŞİL ${ }^{2}$ iD \\ 1,2Faculty of Pharmacy, Department of Pharmaceutical Botany, Istanbul University, Istanbul, Turkey \\ ${ }^{1}$ https://orcid.org/0000-0003-1566-4806, ${ }^{2}$ https://orcid.org/0000-0002-4458-7881 \\ $\varangle$ : onur.tuncay@istanbul.edu.tr
}

\section{ABSTRACT}

Herbs and spices have long been used to improve the flavor of food. Cumin, one of these spices, is widely used all over the world. However different species known as cumin are used for the same purpose. According to the data obtained from ethnobotanical studies in Turkey, four species are known and used as cumin (Kimyon) in the country; Carum carvi L., Cuminum cyminum L., Laser trilobum (L.) Borkh. and Grammosciadium daucoides DC. In this study, comparative fruit anatomy and morphology of species were studied. The purpose of this study was to have easier species identification by revealing the differences between their fruits. Considerable differences were observed in the fruit morphology with different shapes. Also, the fruit surface patterns of species showed important differences with the only similarities of their surfaces were being striated. Carum carvi and Grammosciadium daucoides had prominent striae, while Cuminum cyminum and Laser trilobum sustained slight striae. Species had different fruit anatomical shapes. The extent of costal channels and the presence of secondary and primary ribs were important differences. An identification key based on both morphological and anatomical characters were presented for the studied species.

\section{Research Article}

$\begin{array}{ll}\text { Article History } & \\ \text { Received } & : 17.01 .2019 \\ \text { Accepted } & : 18.04 .2019\end{array}$

Keywords

Apiaceae anatomy

Carum carvi

Cuminum cyminum

Laser trilobum

Grammosciadium daucoides

\title{
Türkiye'de Kimyon Olarak Kullanılan Dört Türün Karşılaştırmalı Meyve Anatomisi ve Morfolojisi
}

\section{ÖZET}

Baharatlar, yemeklere lezzet vermek için uzun zamandan beri kullanılmaktadır. Bu baharatlardan biri de tüm dünyada yaygın olarak kullanılan kimyondur. Kimyon olarak bilinen farklı türler aynı amaç için kullanılmaktadır. Türkiye'deki etnobotanik çalışmalardan elde edilen verilere göre Türkiye'de kimyon olarak kullanılan dört tür bilinmektedir. Bu türler; Carum carvi L., Cuminum cyminum L., Laser trilobum (L.) Borkh. ve Grammosciadium daucoides DC. Bu çalışmada kimyon olarak kullanılan türlerin karşılaştırmalı meyve anatomisi ve morfolojisi incelenmiştir. Bu çalışmanın amacı, meyveler arasındaki anatomik ve morfolojik farkları ortaya çıkararak türlerin birbirinden ayırt edilmesini kolaylaştırmaktır. Bu türlerin meyve morfolojisinde önemli farklılıklar gözlenmiştir. Ayrıca, türlerin meyve yüzeyinde yapılan mikromorfolojik çalışmalarda da belirgin farklılıklar ortaya konulmuştur. Kimyon olarak kullanılan türlerin meyve anatomisi incelendiğinde salgı kanalların yerleşimi ve primer veya sekonder kostaların varlığı gibi önemli farklılıklara rastlanmıştır. Çalışılan türler için hem morfolojik hem de anatomik karakterlere dayanan bir teşhis anahtarı sunulmuştur.

\section{Araştırma Makalesi}

Makale Tarihçesi

Geliş Tarihi : 17.01 .2019

Kabul Tarihi : 18.04 .2019

Anahtar Kelimeler

Apiaceae anatomi

Carum carvi

Cuminum cyminum

Laser trilobum

Grammosciadium daucoides

To Cite : Tuncay HO, Yeşil Y 2019. Comparative Fruit Anatomy and Morphology of Four Species Known as Cumin (Kimyon) in Turkey. KSÜ Tarım ve Doğa Derg 22(4): 547-556. DOI: 10.18016/ksutarimdoga.vi.514009.

\section{INTRODUCTION}

Throughout history, various herbs and spices have been used all over the world to preserve or change the food flavor. People have been using these plants for very long times. Cumin, a popular spice and herb plant in ancient Egypt, was used as a pain killer for cough, digestive system and chest diseases, and for treating 
rotten teeth (Chevallier, 2016). In terms of cooking, cumin is a material found in Indian and Middle Eastern recipes, especially in Chinese cuisine, particularly in curry and pickles. Also, cumin is being used in Central American and Mediterranean cuisines (Chevallier, 2016; Mete, 2017).

The Apiaceae commonly known as carrot or parsley family is one of the largest group among Angiosperm plants (Pimenov and Leonov, 1993; Hickey and King, 1997). There are 455 genera and 3600-3751 species belonging to the family in the world (Pimenov and Leonov 1993, 2004). The family of Apiaceae is represented by 101 genera and 451 species in Turkey and endemism ratio is about 33\% (Özhatay et al., 2009). The morphological and anatomical characteristics of the fruit have important distinctive characteristics for the family (Kızılarslan and Akalın, 2017).

Some species are known as cumin in Turkey; Carum carvi L., Cuminum cyminum L., Laser trilobum (L.) Borkh, Grammosciadium daucoides DC. These species have been used for both culinary and medicinal purposes (Baytop, 1999; Yeşil and Akalın, 2010; Bulut et. al., 2014; Doğan et. al., 2014; Özdemir and Kültür, 2017).

The genus Carum L. has five species in Turkey. Carum carvi is from tribe Apieae (Pimenov and Leonov, 1993). They are fragrant plants that carry essential oils (Hedge et al., 1972a; Tuzlacı, 2011; Menemen, 2012a). Carum carvi is known as caraway seed (Frenk Kimyonu) and used as a spice in Europe and Turkey (Baytop, 1999). Ethnobotanical studies show that Carum carvi is used in folk medicine as appetizer, digestive, aphrodisiac. (Bulut et. al., 2014)

Cuminum cyminum L. is the only Cuminum species in Turkey (Tuzlac1, 2011; Menemen, 2012b). Cuminum cyminum is from tribe Caucalideae (Pimenov and Leonov, 1993). There are 5 ribs easily seen on each mericarp of the schizocarp fruit. Its surface is slightly hairy (Baytop, 1999). Ethnobotanical studies show that Cuminum cyminum is used in folk medicine for the common cold treatments (Güneş et al.,2017).

Laser trilobum is the only species from this genus in Turkey (Hedge et al., 1972b; Tuzlacı, 2011; Menemen, 2012c). Laser trilobum is from tribe Peucedaneae (Pimenov and Leonov, 1993). It is common in Thrace and Anatolia. Due to its distribution, it is obtained from Kastamonu, Zonguldak, Eskişehir, Adana and Konya. In this species, there are 5 primary and 4 secondary rib in each mericarp (Baytop, 1999). It is used as spice in Adana, Çanakkale and Mersin (Tuzlaci, 2011). Ethnobotanical studies show that Laser trilobum is used in folk medicine for treatment of diabetic disease, abdominal pain, digestive and blood pressure therapy (Bulut et. al., 2014; Güneş et al.,2017).
Grammosciadium DC. has 6 species in Turkey. Grammosciadium daucoides is from tribe Scandiceae (Pimenov and Leonov, 1993). Grammosciadium daucoides known as "Kami" used as spice in Malatya (Hedge et al.,1972c; Yeşil and Akalın, 2010; Menemen, 2012d;). There are several anatomical and morphological studies about Grammosciadium (Bani et al., 2016a; Ulusoy et al., 2017).

This study aims to determine the detailed fruit anatomy and morphology of the species known as cumin in Turkey and thus, to reveal the differences between the fruits of these species used as spices.

\section{MATERIALS and METHODS}

Ripe fruits of Carum carvi, Cuminum cyminum, Laser trilobum, Grammosciadium daucoides were obtained from the voucher specimens. The species list, grid, city, altitude and herbarium number of Istanbul University Faculty of Pharmacy (ISTE) are given in Table 1. Anatomical research material was dried so firstly they were kept in distilled water then they were preserved in $70 \%$ ethanol. In this study, measurements were taken from at least 6 mature fruits of different herbarium samples of each of 4 species. The numbers and information of the herbarium samples studied are given in Table 1. All transverse sections were cut by hand from the middle of the mericarps using a blade. Samples were examined in Sartur reagent (a compound reagent of lactic acid, Sudan III, aniline, iodine, potassium iodide, alcohol, and water) (Çelebioğlu and Baytop, 1949). Photographs were taken via iPhone $6 \mathrm{~s}$ and measurements of mericarps were made by KAMERAM $\odot$ computer software. The fruit morphology and anatomy were described by using Botanical Latin (Stearn, 2005); Kızlarslan and Akalın (2017). The fruit micromorphology was described by Stearn (2005), Aksenov et al. (1972), Özcan (2004); Bani et al. (2016a, b); Liu and Downie (2017).

\section{RESULTS}

\section{Macromorphological Characteristics of Fruits}

General views of the fruits are shown in Figure 1. The macromorphological characteristics of fruits are listed in Table 2. Carum carvi fruits (Figure 1a) are 4-6 mm long and fruit shape is narrowly elliptic. Fruits are brown or bright yellowish brown in color and glabrous. It consists 5 light yellow colored dorsal ribs that are visible in each mericarp.

Cuminum cyminum fruits (Figure 1b) are 5-6 mm long and spindle-shaped and yellowish brown colored granules. There are 5 dorsal ribs that are easily seen on each mericarp. The color between the rib is brown and fruit is sparse pubescent.

Laser trilobum fruits (Figure 1c) are 5-10 mm long and 2-4 mm wide, fruit shape is elliptic. Each mericarp has 5 primary and 4 secondary dorsal ribs. 
Table 1 . The list, city and collection numbers of the studied species

\begin{tabular}{|c|c|c|c|c|}
\hline Species & Grid & City & Altitude & Collection Number \\
\hline \multirow[t]{2}{*}{ Carum carvi } & A9 & Kars & $2000 \mathrm{~m}$ & ISTE 59366 \\
\hline & A9 & Kars & $2000 \mathrm{~m}$ & ISTE 18351 \\
\hline \multirow[t]{2}{*}{ Cuminum cyminum } & B3 & Eskişehir & $800 \mathrm{~m}$ & ISTE 56924 \\
\hline & C6 & Gaziantep & - & ISTE 56938 \\
\hline \multirow[t]{5}{*}{ Laser trilobum } & A6 & Samsun & - & ISTE 77603 \\
\hline & $\mathrm{A} 1$ & Kırklareli & - & ISTE 29918 \\
\hline & $\mathrm{A} 4$ & Çankırı & $1700 \mathrm{~m}$ & ISTE 35270 \\
\hline & $\mathrm{A} 4$ & Zonguldak & - & ISTE 49146 \\
\hline & C3 & Isparta & $1300 \mathrm{~m}$ & ISTE 103408 \\
\hline \multirow[t]{4}{*}{ Grammosciadium daucoides } & B9 & Ağrı & $2020 \mathrm{~m}$ & ISTE 42701 \\
\hline & A6 & Sivas & $1800 \mathrm{~m}$ & ISTE 102054 \\
\hline & $\mathrm{C} 6$ & Malatya & $1550 \mathrm{~m}$ & ISTE 101986 \\
\hline & B7 & Erzincan & $2100 \mathrm{~m}$ & ISTE 74633 \\
\hline
\end{tabular}
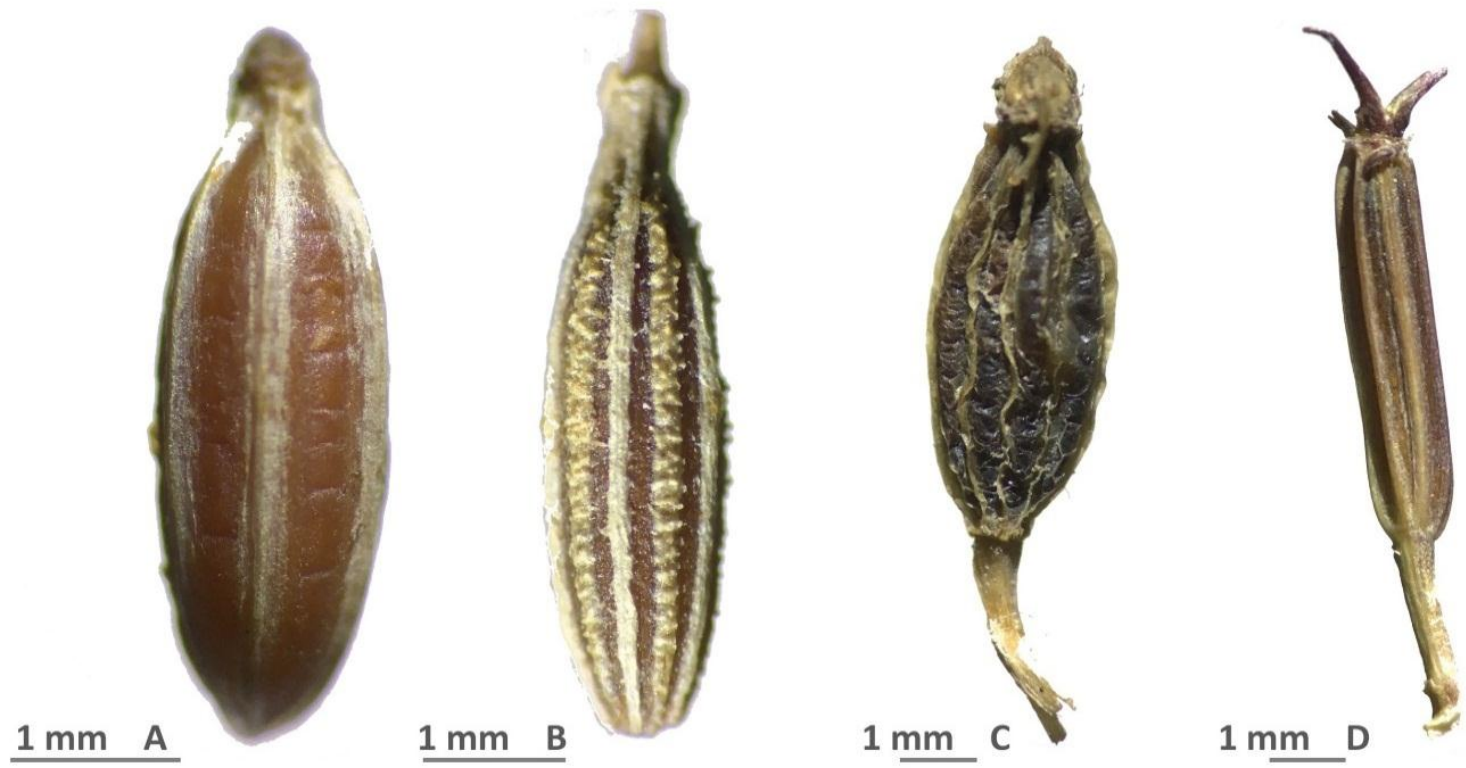

Figure 1. General view of the fruits; A Carum carvi, B Cuminum cyminum, C Laser trilobum, D Grammosciadium daucoides

Grammosciadium daucoides fruits (Figure 1d) are 7-11 $\mathrm{mm}$ in length, fruit shape is lorate and the calyx is persistent in the fruit. There are 5 dorsal ribs in each mericarp.

\section{Fruit Micromorphology}

The features of the mericarp surface are shown in Figure 2 and Figure 3. Distinguishing properties were observed on the fruits surfaces (Table 2).

\section{Carum carvi}

The ornamentation pattern is rugose-striate type. The fruit surface is very strongly striate on whole surface and it is rugose on the surface of ribs, it is more intensely rugose on the vallecular surface.

\section{Cuminum cyminum}

The surface pattern is striate type, while the fruit surface has micropapillae particularly on the surface of ribs, has few on the vallecular surface. Striae can be observed on the whole surface.

\section{Laser trilobum}

The ornamentation pattern is rugose-striate type with densely rugose on surfaces of ribs and slightly corrugated on vallecular surfaces. Striae can be observed on vallecular surfaces.

\section{Grammosciadium daucoides}

The ornamentation pattern is rugose-favulariate type on both surfaces of ribs. The surface has frequent and prominent striate. 
Table 2. Measurement and properties of the fruits of the examined species.

\begin{tabular}{|c|c|c|c|c|}
\hline Features & Carum carvi & $\begin{array}{l}\text { Cuminum } \\
\text { cyminum }\end{array}$ & Laser trilobum & $\begin{array}{l}\text { Grammosciadium } \\
\text { daucoides }\end{array}$ \\
\hline $\begin{array}{l}\text { Mericarp width } \\
\text { Average (min-max) }\end{array}$ & $\begin{array}{ll}1.58 & \mathrm{~mm} \\
(1.55-1.6) & \end{array}$ & $\begin{array}{l}1.84 \quad \mathrm{~mm} \\
(1.82-1.86)\end{array}$ & $\begin{array}{l}3.31 \mathrm{~mm} \\
(3.21-3.42)\end{array}$ & $\begin{array}{l}1.42 \mathrm{~mm} \\
(1.35-1.44)\end{array}$ \\
\hline $\begin{array}{l}\text { Mericarp length } \\
\text { Average (min-max) }\end{array}$ & $\begin{array}{l}1.41 \mathrm{~mm} \\
(1.39-1.42)\end{array}$ & $\begin{array}{l}1.1 \mathrm{~mm} \\
(1.08-1.14)\end{array}$ & $\begin{array}{l}1.11 \mathrm{~mm} \\
(0.98-1.24)\end{array}$ & $\begin{array}{l}1.13 \mathrm{~mm} \\
(1.12-1.15)\end{array}$ \\
\hline $\begin{array}{l}\text { Ratio of width to length of } \\
\text { mericarp }\end{array}$ & 1.117 & 1.668 & 2.97 & 1.254 \\
\hline $\begin{array}{l}\text { Vallecular vittae width } \\
\text { Average (min-max) }\end{array}$ & $\begin{array}{l}0.18 \quad \mathrm{~mm} \\
(0.16-0.22)\end{array}$ & $\begin{array}{l}0.19 \mathrm{~mm} \\
\left(0.16^{-0.22)}\right.\end{array}$ & $\begin{array}{ll}0.29 & \mathrm{~mm} \\
(0.21-0.34) & \end{array}$ & $\begin{array}{l}0.2 \\
(0.16-0.23)\end{array}$ \\
\hline $\begin{array}{l}\text { Vallecular vittae length } \\
\text { Average (min-max) }\end{array}$ & $\begin{array}{l}0.045 \mathrm{~mm} \\
(0.036-0.056)\end{array}$ & $\begin{array}{l}0.046 \quad \mathrm{~mm} \\
(0.04-0.057)\end{array}$ & $\begin{array}{l}0.097 \\
(0.063-0.12)\end{array}$ & $\begin{array}{l}0.052 .9 \\
(0.042-0.055)\end{array}$ \\
\hline $\begin{array}{l}\text { Commissural vitae width } \\
\text { Average (min-max) }\end{array}$ & $\begin{array}{l}0.115 \quad \mathrm{~mm} \\
(0.111-0.119)\end{array}$ & $\begin{array}{l}0.227 \mathrm{~mm} \\
(0.189-0.249)\end{array}$ & $\begin{array}{ll}0.3 & \mathrm{~mm} \\
(0.23-0.39) & \end{array}$ & $\begin{array}{l}0.2 \\
(0.15-0.25)\end{array}$ \\
\hline $\begin{array}{l}\text { Commissural vitae length } \\
\text { Average (min-max) }\end{array}$ & $\begin{array}{l}0.035 \mathrm{~mm} \\
(0.023-0.042)\end{array}$ & $\begin{array}{l}0.044 \quad \mathrm{~mm} \\
(0.027-0.054)\end{array}$ & $\begin{array}{ll}0.059 & \mathrm{~mm} \\
(0.04-0.1) & \end{array}$ & $\begin{array}{l}0.045 \\
(0.029-0.059)\end{array}$ \\
\hline Oil duct & rib & rib & rib (sparse) & rib (sparse) \\
\hline Hypodermal collenchyma & single line & 2-3 lines & single line & 2-3 lines \\
\hline $\begin{array}{l}\text { Shape of mericarp in } \\
\text { transversal section }\end{array}$ & $\begin{array}{l}\text { latissime } \\
\text { ovatus }\end{array}$ & $\begin{array}{l}\text { depresse } \\
\text { ovatus }\end{array}$ & $\begin{array}{l}\text { transverse } \\
\text { anguste } \\
\text { elipticus }\end{array}$ & latissime ovatus \\
\hline Surface of fruit & glabrous & $\begin{array}{l}\text { sparsely } \\
\text { pubescent }\end{array}$ & glabrous & glabrous \\
\hline Length and shape of fruit & $\begin{array}{l}\text { 4-6 mm long, } \\
\text { narrowly } \\
\text { elliptic }\end{array}$ & $\begin{array}{l}\text { 5-6 mm long, } \\
\text { spindle-shaped }\end{array}$ & $\begin{array}{l}\text { 5-10mm long, } \\
\text { elliptic }\end{array}$ & $\begin{array}{l}\text { 7-11 mm long, } \\
\text { elliptic }\end{array}$ \\
\hline $\begin{array}{l}\text { Number of dorsal ribs in } \\
\text { each mericarp }\end{array}$ & 5 & 5 & $\begin{array}{l}5 \text { primary and } 4 \\
\text { secondary }\end{array}$ & 5 \\
\hline $\begin{array}{l}\text { The micromorphological } \\
\text { properties of fruit surface }\end{array}$ & rugose-striate & striate & rugose-striate & rugose-favulariate \\
\hline
\end{tabular}

\section{Fruit Anatomy}

The fruits of all species consist of 2 homomorphic mericarps. Fruits were examined under separate headings. The transversal sections of mericarps are shown in Figure 4. Measurement and properties of the fruits of the examined species are given in Table 2.

\section{Carum carvi}

The shape of mericarp is latissime ovatus in transversal section (Figure 4A).

Exocarp: Cuticula is usually thin and smooth. Exocarp consists of single line, thick walled and isodiametric cells. A single line hypodermal collenchyma is seen. Exocarp continues towards the commissural area of 2 mericarps.

Mesocarp: Vascular bundles are placed in the 5 ribs but the valecular vittae are larger and vaguely elongated. Valecular vittae usually 4, commissural vittae 2. Commissural vittae smaller than valecular vittae. Each vascular bundle upper side is accompanied by some sclerenchymatous tissue. Trachea and tracheids are not distinguished from each other in xylem. Oil ducts are located in ribs.

Endocarp: Composed of single line, narrow-long and thin-walled cells. Endocarp was observed to be 2 lines under vallecular vittae. Endoderm cells are shortened between raphe (connecting seed to pericarp) and carpophore (connecting 2 mericarps to each other). Cell walls are lignified. Druse crystals are observed. 

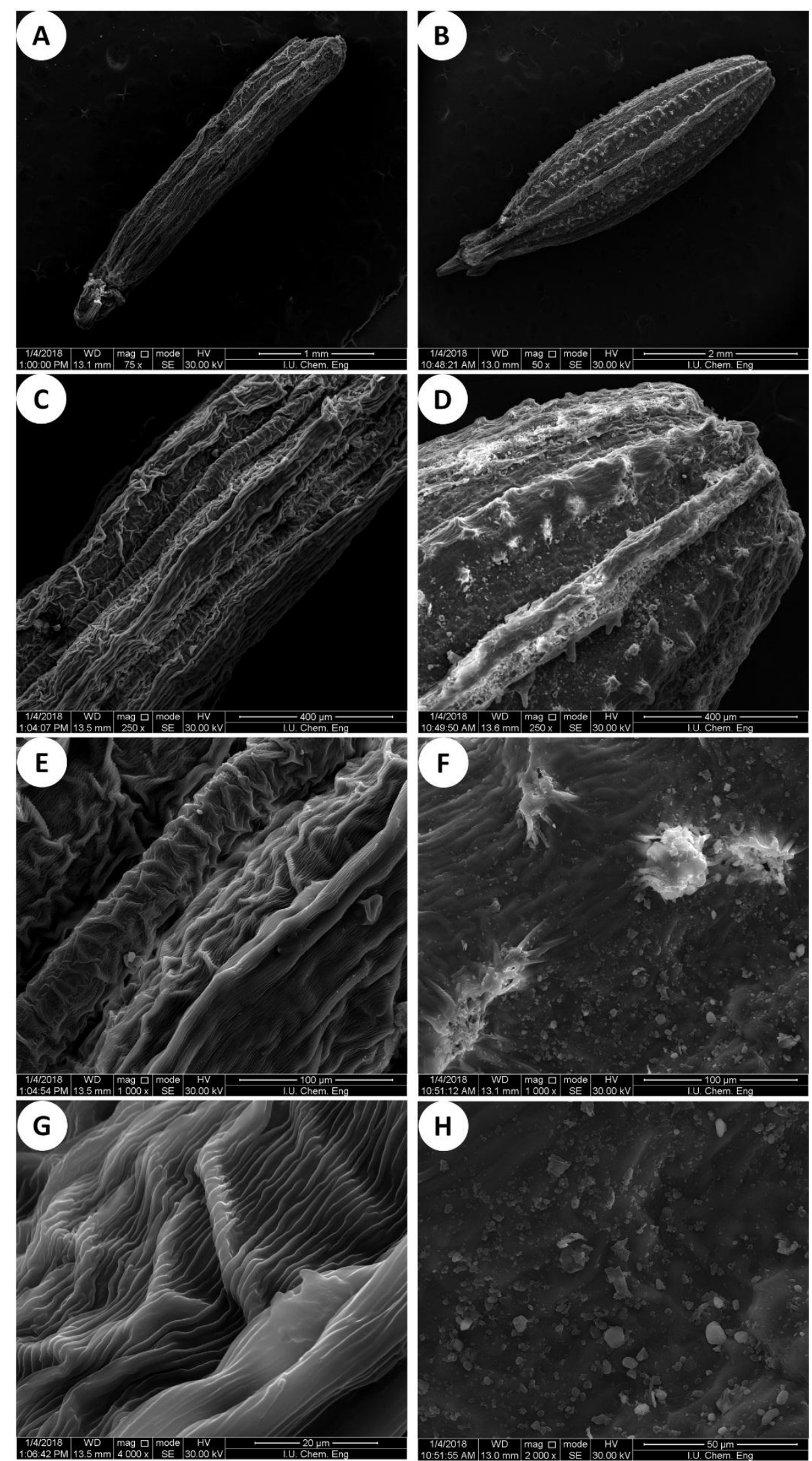

Figure 2. SEM micrographs of fruit surface in Carum carvi A, B, C, D; Cuminum cyminum E, F, G, H. 

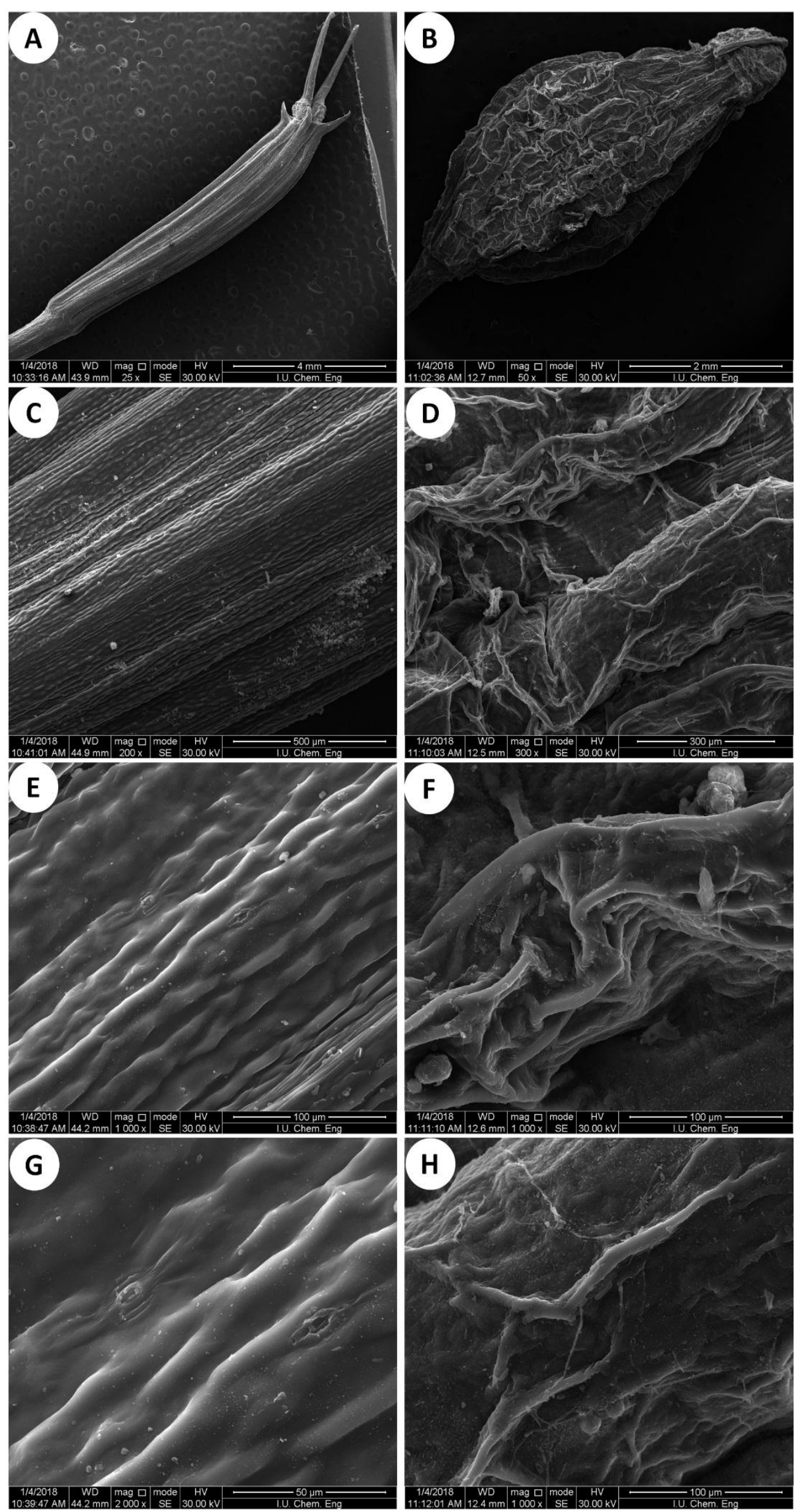

Figure 3.SEM micrographs of fruit surface in Grammosciadium daucoides A, B, C, D; Laser trilobum E, F, G, H. 

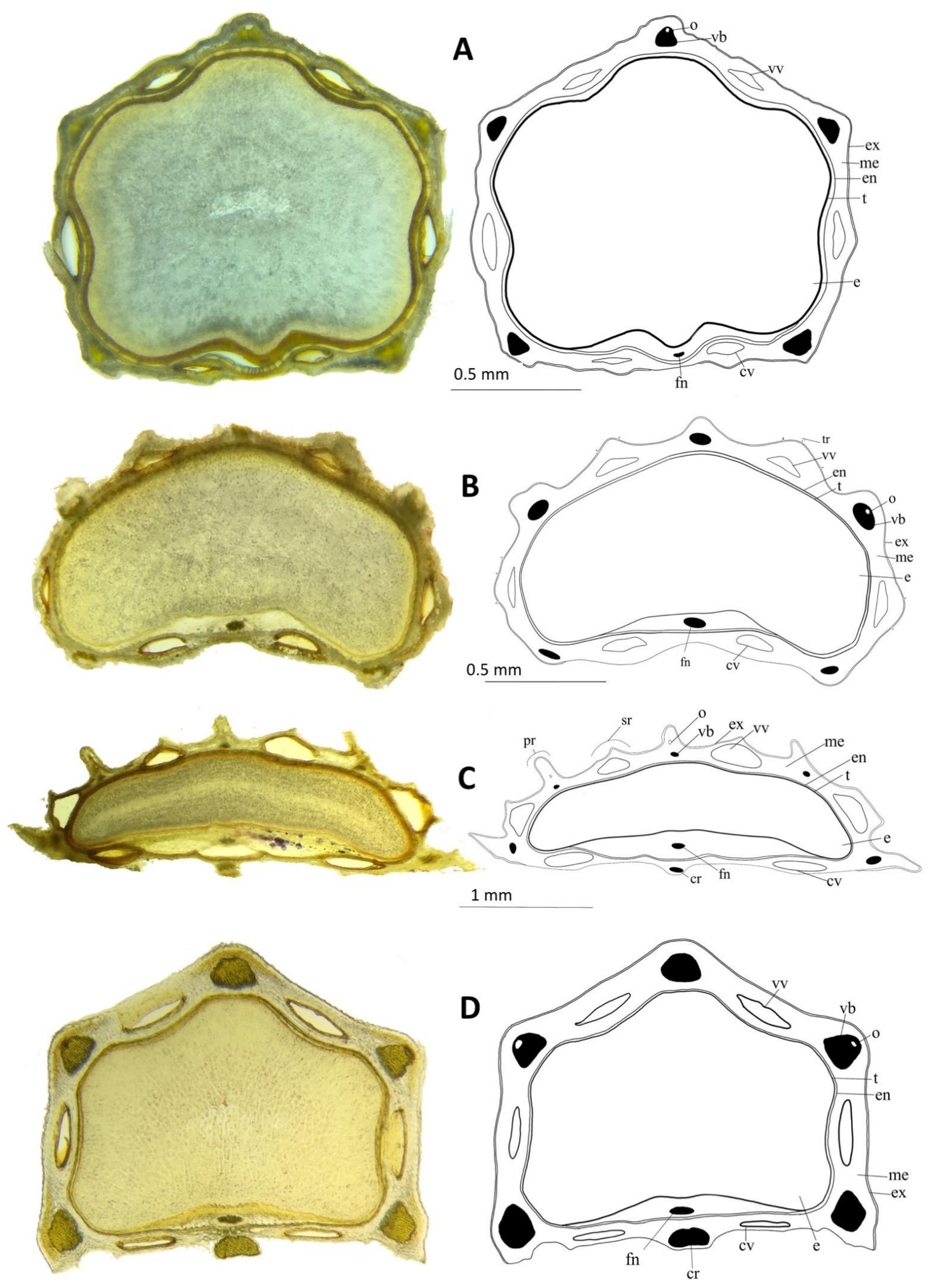

$0.5 \mathrm{~mm}$

Figure 4. The transversal section of mericarps; A Carum carvi, B Cuminum cyminum, C Laser trilobum, D Grammosciadium daucoides. cr carpophore, cv commissural vittae, e endosperma, en endocarp, ex exocarp, fn funicle, me mesocarp, o oil duct, pr primary rib, sr secondary rib, t testa, tr trichome, vb vascular bundle, vv vallecular vittae. 


\section{Cuminum cyminum}

The shape of mericarp is depressed ovatus in transversal section (Figure 4B).

Exocarp: Cuticula is usually thin and smooth. 2-3 line hypodermal collenchyma is seen. Exocarp continues towards the commissural area of 2 mericarps.

Mesocarp: Vascular bundles are placed in the 5 ribs. Valecular vittae usually 4, commissural vittae 2. Commissural vittae is bigger than valecular vittae. Oil ducts are located in ribs. Sclerenchymatous tissue around the vascular bundles was observed to be minimal.

Endocarp: Composed of single line, narrow-long and thick-walled cells. Druse crystals are observed.

\section{Laser trilobum}

The shape of mericarp is transverse anguste elipticus in transversal section (Figure 4C).

Exocarp: Cuticula is usually thin and smooth. Exocarp consists of single line, thick walled and isodiametric cells. A single line hypodermal collenchyma is seen.

Mesocarp: Vascular bundles are placed in the 5 primary ribs. Valecular vittae usually 4, commissural vittae 2. Valecular vittaes are placed in the 4 secondary ribs. Commissural vittae is bigger than valecular vittae. Oil ducts are rarely located in ribs. Sclerenchymatous tissue around the vascular bundles was observed to be minimal.

Endocarp: Composed of single line, narrow-long and thick-walled cells. Testa has the thick layer. Druse crystals are observed.

\section{Grammosciadium daucoides}

The shape of mericarp is transverse latissime ovatus in transversal section (Figure 4D).

Exocarp: Cuticula is usually thin and smooth. Exocarp consists of single line, thick walled and isodiametric cells. 2-3 lines hypodermal collenchyma is seen. Exocarp continues towards the commissural area of 2 mericarps.

Mesocarp: Vascular bundles are placed in the 5 ribs. Valecular vittae usually 4, commissural vittae 2. The dimension of vallecular vittae and commissural vittae are approximately the same. Each vascular bundle is accompanied by some sclerenchymatous tissue. Sclerenchymatous tissue is thick especially underside of vascular bundle. Trachea and tracheids are not distinguished from each other in xylem. Oil ducts are rarely located in ribs.

Endocarp: Composed of single line, narrow-long and thick-walled cells. Testa is thick layer especially at commissural surface. Druse crystals are observed.

\section{DISCUSSION}

This study includes 4 species used as cumin in the Apiaceae family in Turkey. When these species are examined, it is seen that they belong to different tribes (Pimenov and Leonov, 1993). Although these species are from different tribes, they have a common purpose of use. Significant differences have been observed in the fruit anatomy and morphology of these plants.

Firstly, the differences in the shape of the fruit can be specified. Shapes of fruits are narrowly eliptic in Carum carvi, spindle-shaped in Cuminum cyminum, eliptic in Laser trilobum, lorate in Grammosciadium daucoides. In addition, the fruit sizes are also different. Among these species only surface of Cuminum cyminum is sparsely pubescent. Each mericarp has 5 primary ribs. Only Laser trilobum has 4 secondary ribs.

Fruits' micromorphological characteristics are very important for the classification of the Apiaceae family (Özcan, 2004; Liu and Downie, 2017; Ostroumova et al., 2010). The fruit surfaces of species show distinct differences, the only similarities of their surfaces are being striated. However, Carum carvi and Grammosciadium daucoides have prominent striae, Cuminum cyminum and Laser trilobum have slight striae. Also, Carum carvi, Cuminum cyminum and Laser trilobum have different surface patterns at primary and secondary ribs. But Grammosciadium daucoides contains only one kind of rib, so it does not have different surface pattern. The results of fruit surface of Grammosciadium daucoides supports the Bani et al.'s (2016b) study.

There are also differences in shape of fruit transversal sections. Shape of mericarp in transversal section; Carum carvi latissime ovatus, Cuminum cyminum depressed ovatus, Laser trilobum transverse anguste elipticus, Grammosciadium daucoides transverse latissime ovatus. Hypodermal collenchyma is single line in exocarp of Carum carvi and Laser trilobum while hypodermal collenchyma is multi lines (2-3) in exocarp of Cuminum cyminum and Grammosciadium daucoides.

Oil ducts are located in ribs. Oil ducts are more common in Carum carvi and Cuminum cyminum than in Laser trilobum and Grammosciadium daucoides. Width of vallecular vittae and commissural vittae are much bigger in Laser trilobum than others 3 species. The endoderm cells are shortened and lignified especially on the commissural surface in Carum carvi. Druse crystals are observed in all species which are examined. The results of fruit anatomy of Carum carvi supports the Zakharova's (2010) study. 
Identification Key for Species Known as Cumin in Turkey

This key has been prepared based on morphological and anatomical characteris Cumunumtics of the fruit of the species.

1. Fruit hairy and shape of mericarp depressed ovatus

Cuminum cyminum

1. Fruit not hairy and shape of mericarp not depressed ovatus

2. Mericarp consists of 5 primers and 4 secondary ribs Laser trilobum

2. Mericarp consists of 5 ribs 3.

3. Commissural vittae width $0.2 \mathrm{~mm}(0.15-0.25)$ Grammosciadium daucoides

3. Commissural vittae width $0.115 \mathrm{~mm}$ (0.111-0.119)

Carum carvi

\section{CONCLUSION}

There are many species that are used as spices in the Apiaceae family. The parts of these plants that are used are usually fruit. This study includes some species used as cumin in the Apiaceae family in Turkey. Fruit anatomy and morphology of these species were compared. Thus, differences between these species have been revealed. Fruit anatomy and morphology are very important in distinguishing these species. The detailed anatomical and morphological results will allow separation of these species easily. This study will allow identification of the species from the fruit sample.

\section{ACKNOWLEDGEMENTS}

We would like to thank to Prof. Dr. Emine Akalın Uruşak (Istanbul University) for her valuable comments. Thanks to Fatma Betül Aydın for her contributions. This work was supported by Scientific Research Projects Coordination Unit of Istanbul University, Project number: 25239.

\section{CONFLICTS of INTEREST}

The authors declared no conflict of interest.

\section{REFERENCES}

Aksenov ES, Tikhomirov VN 1972. Klyuch dlya opredeleniya po plodam vidov roda Pimpinella L. flory USSR. Byulleten Glavnogo botanicheskogo sada (Moscow), 85: 35-45.

Bani B, Ulusoy F, Karakaya MA, Koch MA 2016a. Taxonomic implications from morphological and anatomical studies in the section Stenodipterafrom the genus Grammosciadium (Apiaceae). PhytoKeys, 68: 73-89.

Bani B, Karakaya MA, Çeter T 2016b. Fruit micromorphological characters of the genus Grammosciadium DC. (Apiaceae) in Turkey. Phytotaxa, 246(2): 184-91.

Baytop T 1999. Türkiye'de Bitkiler İle Tedavi. Nobel
Tip Kitabevleri, İstanbul.

Bulut G, Tuzlacı E, Doğan A, Şenkardeş İ 2014. An ethnopharmacological review on the Turkish Apiaceae species. Journal of Faculty Pharmacy of Istanbul University, 44(2): 163-179.

Chevallier A 2016. Encyclopedia of Herbal Medicine: 550 Herbs and Remedies for Common Ailments, Third ed., Dorling Kindersley Book, NY, 197p.

Çelebioğlu S, Baytop T 1949. A New Reagent for Microscopical Investigation of Plant. 10. Publication of the Institute of Pharmacognosy, $301 p$.

Doğan A, Şenkardeş İ, Bulut G, Tuzlacı 2014. An ethnopharmacological review on the Turkish Apiaceae species. Journal of Faculty Pharmacy of Istanbul University, 44(2): 163-179.

Güneş S, Savran A, Paksoy MY, Koşar M, Çakılcıŏlu U 2017. Ethnopharmacological survey of medicinal plants in Karaisalı and its surrounding (AdanaTurkey). Journal of herbal medicine, 8: 68-75.

Hedge IC, Lamond JM 1972a. Carum L. (Flora of Turkey and the East Aegean Islands, vol 4. Edinburgh University Press, Edinburgh: Ed. Davis PH) 319.

Hedge IC, Lamond JM 1972b. Laser Borkh. (Flora of Turkey and the East Aegean Islands, vol 4. Edinburgh University Press, Edinburgh: Ed. Davis PH) 513.

Hedge IC, Lamond JM 1972c. Grammosciadium DC. (Flora of Turkey and the East Aegean Islands, vol 4. Edinburgh University Press, Edinburgh: Ed. Davis PH) 347-348.

Hickey M, King C 1997. Common Families of Flowering Plants. Cambridge University Press, Cambridge.

Kızılarslan Hançer Ç, Akalın Uruşak E 2017. Term of "Vitta" and Their Localization in Fruit Anatomy of Apiaceae Family. Avrasya Terim Dergisi, 5(2): 1924.

Liu M, Downie SR 2017. The Phylogenetic Significance of Fruit Anatomical and Micromorphological Structures in Chinese Heracleum Species and Related Taxa (Apiaceae). Systematic Botany, 42(2): 313-325.

Menemen Y 2012a. Carum L. (Türkiye Bitkileri Listesi/Damarlı Bitkiler, Nezahat Gökyiğit Botanik Bahçesi ve Flora Araştırmaları Derneği Yayını, Istanbul: Ed Güner A, Aslan S, Ekim T, Vural M, Babaç MT) 55 .

Menemen Y 2012b. Cuminum L. (Türkiye Bitkileri Listesi/Damarlı Bitkiler, Nezahat Gökyiğit Botanik Bahçesi ve Flora Araştırmaları Derneği Yayını, Istanbul: Ed Güner A, Aslan S, Ekim T, Vural M, Babaç MT) 57.

Menemen Y2012c Laser Borkh. (Türkiye Bitkileri Listesi/Damarlı Bitkiler, Nezahat Gökyiğit Botanik Bahçesi ve Flora Araştırmaları Derneği Yayını, Istanbul: Ed Güner A, Aslan S, Ekim T, Vural M, 
Babaç MT) 68.

Menemen Y 2012d. Grammosciadium DC. (Türkiye Bitkileri Listesi/Damarlı Bitkiler, Nezahat Gökyiğit Botanik Bahçesi ve Flora Araştırmaları Derneği Yayını, Istanbul: Ed Güner A, Aslan S, Ekim T, Vural M, Babaç MT) 65.

Mete O 2017. Baharatlar. Alfa Basım Yayım Dağıtım San. Ve Tic. Ltd. Şti, İstanbul, 206-207p.

Ostroumova TA, Pimenov MG, Ukrainskaya UA 2010. Micromorphological diversity of hairs and emergences on fruits in the Umbelliferae and its taxanomic value. Botanicheskij Zhurnal, 95(9): 1219-1231.

Özdemir E, Kültür Ş 2017. Wild edible plants of savaştepe district (Ballkesir, Turkey). Marmara Pharmaceutical Journal, 21(3): 578-589.

Özcan T 2004. Analysis of the fruit surfaces in Bupleurum L. (Umbelliferae) with SEM. Plant Systematic and Evolution, 247: 61-67.

Özhatay N, Akalın E, Özhatay E, Ünlü S 2009. Rare and Endemic Taxa of Apiaceae in Turkey and Their Conservation Significance. J. Fac. Pharm. Istanbul, 40.
Pimenov MG, Leonov MV 1993. The Genera of the Umbelliferae. Royal Botanic Gardens, Kew.

Pimenov MG, Leonov MV 2004. The Asian Umbelliferae Biodiversity Database (ASIUM) with Particular Reference to South-West Asian Taxa. Turkish Journal of Botany, 28: 139-145.

Stearn WT 2005. Botanical Latin. Timber Press, Portland.

Tuzlacı E 2011. Türkiye'nin yabani besin bitkileri ve ot yemekleri. Alfa Basım Yayım Dağıtım San. Ve Tic. Ltd. Şti., İstanbul.

Ulusoy F, Karakaya MA, Mavi Idman DO, Bani B 2017. A new diagnostic character in the roots of the genus Grammosciadium DC. (Apiaceae). Phytotaxa, 292(2):150-160. [CrossRef]

Yeşil Y, Akalin Uruşak E 2010. The Use of Wild Edible Plants in Kürecik (Akçadağ/Malatya). J. Fac. Pharm. Istanbul, 41: 90-103.

Zakharova EA 2010. Morphological evidence of polyphyletic nature of traditional Carum (ApiaceaeApioideae). Plant Div. Evol., 128: 409-421. 